that the book falls short. The contributions of pulse radiolysis to reaction kinetics and electron transfer reactions are not brought out and discussed in relation to rate theory. The potential of the method in physical inorganic chemistry is similarly ignored. The high degree of specificity of systems that, when irradiated, will produce a single radical species, for example $\mathrm{OH}, \mathrm{H}$ or $\mathrm{e}^{-}{ }_{\text {aq }}$, the reactions of which can then be studied, in many cases directly, is an important aspect of contemporary radiation chemistry when viewed in the wider context of physical chemistry.

The authors can also be somewhat uncritical, for example their belief that $\mathrm{OH}$ rate constant data obtained by thiocyanate competition are "practically of no use" is not a balanced judgment and unjustifiably condemns a great deal of useful data.

In conclusion, although this book is a useful introductory volume to the subject it does not assess the achievements and potential of radiation chemistry in relation to physical chemistry sufficiently well.

E. M. FIELDEN

\section{Lunar Temperature}

Thermal Characteristics of the Moon. Edited by John W. Lucas. Pp. xiiit 340. (MIT: Cambridge, Massachusetts, and London, 1972.) \$14.95.

THrough this volume, leading investigators in different disciplines have combined to survey the temperatures and physical properties of the surface and interior of the Moon. Their accounts relate essentially to the achievements of the past decade-from pre-Ranger times through the present epoch of continuing spaceflight exploration of the Moon-and have been organized under four broad headings: measurements made from the Earth (82 pages); those made on the Moon itself (94 pages); those made on simulated lunar (or lunar-like) materials (56 pages); and the possible thermal history of the Moon (38 pages).

The overall subject matter of a book such as this might well have been drawn from some conference; this work, however, is much better organized and balanced than the average conference presentation. Each author has tended to give a fair review-frequently with a summary-of his subject, rather than to argue strongly for his particular point of view. Inevitably, therefore, much of the content is of old material-a bias which, taken together with the hindsight and caution which enter the various accounts and punctuated in the light of recent advances by the expert authors themselves, is wholly desirable.

Both lunar specialists and scientists in other fields are likely to benefit from this book. It is quite well written; it collects together previously detached arguments apposite to the general lunar thermal problem; and it brings the subject right up to date with a brief account of the puzzlingly high heat flow from within the Moon recorded by the thermal probes inserted in the lunar soil, near to the Hadley Rille, by the Apollo 15 astronauts. Neither the immediate difficulties in explaining this high heat flux-nor the importance of the results--were lessened by the failure of the similar experiment set up by the Apollo 16 team.

G. FIELDER

\section{Flora of North America}

The Genera of North American Plants. By Thomas Nuttall. Introduction by J. Ewan. Vol. 1. Pp. xxxvii+vii +312 . Vol. 2. Pp. $254+10$. Facsimile of the 1818 edition. Classica Botanica Americana, Vol. 7. (Hafner: New York, 1971.) $\$ 14.65$.

Flora of the Prairies and Plains of Central North America. By Per Axel Rydberg. Vol. 1. Pp. 1-504. Vol. 2. Pp. 505-969. Facsimile of the 1932, 1 volume, edition. (Dover: New York; Constable: London, April 1972.) \$5; $£ 2.50$ each volume.

IT is unfortunate for the modern botanist that the present boom in antiquarian book prices is offset by ambitious reprint programmes from certain publishers. Hafner's Classica Botanica Americana series provides a good example of a systematic approach to the provision of durable reprints of rare, expensive, and often fragile classics. When such reprints are enriched by the inclusion of a scholarly apparatus like Ewan's introduction to Nuttall the exercise becomes doubly worth while.

Nuttall, a Yorkshireman, emigrated to America in 1808 and soon took to botany under the influence of Benjamin Smith Barton. His Genera, published a decade later, provided a masterly conspectus of contemporary knowledge on the North American flora. Written in English and following the Linnaean system it was of immediate value to the botanical student and amateur. Furthermore, Nuttall's wide travels resulted in a breadth of knowledge that made the Genera a valuable foundation for later floras. Professor Ewan's excellent introduction provides information on the author, his travels, collections, researches and influence as well as the taxonomic value of the Genera for the modern botanist. In addition, there is a useful gazetteer of place names and a clarification of literature references used in the text.

Rydberg, like Nuttall, emigrated to America (from Sweden) at the age of
22. He also travelled very widely and took to writing large scale floras of which the present was his last. This concise work, well provided with keys and illustrations, treats of 1,066 genera (3,988 spp.) compared with Nuttall's 834. Though still in considerable demand this 40-year-old flora would have benefited from a new introduction commenting on its practical and taxonomic worth to the modern botanist. An otherwise utilitarian reprint suffers from division into two volumes which must hamper use in the field.

G. D. R. BRIDSON

\section{Connective Tissue}

Journal of Connective Tissue Research. Editor-in-chief, Ines Mandl. Vol. 1. No. 1. (Gordon and Breach: New York, London and Paris, March 1972.) Personal subscription, $£ 5.50$ per volume. Libraries, institutions, etc., $£ 15.50$ per volume.

WE read after the foreword to this new journal that when an eminent researcher on the subject first heard of it his reaction was unprintable. His mature consideration was that it was not a bad idea. I also find myself with both types of reaction but only time will tell whether the second is appropriate. The familiar problem is raised of whether journals should be according to the subject investigated or according to the method used. Both subject and method are specialities, both require the interaction of specialists to flourish, so probably both types of journal are equally useful. Connective tissue research is a wider field than some already supporting journals. So far, so good. When we examine this issue there are further promising signs. There could not be a better board assembled to administer a journal in this subject and there are a number of significant papers in the first issue. At the level of molecular interaction there is a paper on one of the polymorphic aggregates of the tropocollagen molecule and another which reports that a polymorphic form usually considered artificial is observed in vivo. The nature of the intermolecular forces is investigated by new methods of solubilizing collagen and there are two papers on the intermolecular cross-links. Two papers are included on elastin, one of which reports that under the scanning electron microscope this material appears to be composed of fibres embedded in an amorphous matrix. Further topics dealt with are cartilage, basement membrane and the collagen of cornea.

It is obvious that this issue is good and this journal is suitable as a repository for reports on connective tissue research in the future. Whether 